\title{
Investigations of Cutting Tool Wear While Machining Inconel 718
}

\author{
Jana Petru ${ }^{1}$, Jan Schiffner ${ }^{1}$, Tomas Zlamal ${ }^{1}$, Marek Sadilek ${ }^{1}$, Dana Stancekova ${ }^{2}$ \\ ${ }^{1}$ Faculty of Mechanical Engineering, VSB-Technical University of Ostrava, 17. listopadu 15/2172, Ostrava, Czech Re- \\ public.E-mail: jana.petru@vsb.cz, jan.schiffner.st@vsb.cz, tomas.zlamal@vsb.cz, marek.sadilek@vsb.cz. \\ ${ }^{2}$ Faculty of Mechanical Engineering, University of Zilina, Univerzitni 8215/1, 01026 Zilina, Slovak Republic. E-mail: \\ dana.stancekova@fstroj.uniza.sk
}

This contribution describes the progress of wear and influences contributing to wear of a cutting tool during straightturning of the Nickel superalloy Inconel 718 according to W. Nr 2.4668. According to the ISO 513 standard this alloy belongs among heat resistant materials; it is a special Nickel alloy used primarily for machine parts in the aircraft industry. The experimental part was done for the purpose of testing suitability of proposed exchangeable cutting inserts intended for machining of Inconel 718. Mechanisms and magnitude of wear and durability of the tools were determined in accordance with the ISO 3685:1993 standard in order to evaluate suitability of the proposed tools.

Keywords: Inconel 718, machining, cutting tool, durability, mechanism and criteria of wear

\section{References}

[1] NESLUSAN, M., CZAN, A. (2001). Obrabanie titanovych a niklovych zliatin. Zilina: Zilinska univerzita v Ziline / EDIS. 189 pp. ISBN 80-7100-933-4.

[2] DURAND-CHARRE, M. (1997). The Microstructure of Superalloys. Gordon \& Breach Science Publisher, Amsterdam. 121 pp. ISBN 109056990977.

[3] PETRU, J., PETRKOVSKA, L., ZLAMAL, T., MRKVICA, I. (2014). Resistance of Sintered Carbide Materials against Heat Shocks Induced by Cutting Process. In METAL 2014 Conference Procedings of the 23Rd International Conference on Metallurgy and Materials, Czech Republic, Brno May 21st - 23rd. Ostrava: TANGER Ltd., 2014, 1st edition, pp. 1 - 6 + proceedings on CD. ISBN 978-80-87294-52-9.

[4] ZAJAC, J., JURKO, J., CEP, R. (2006). Top trendy v obrabani, II cast - Nastrojove materialy. Zilina: Media/St, s.r.o. Zilina. 193 pp. ISBN 80-968954-2-7.

[5] ISO 3685:1993 (1993). Tool-life testing with single-point turning tools. Geneva, International Organization for Standardization, $48 \mathrm{pp}$.

[6] Modern Metal Cutting, A practical Handbook, Sandvik Coromant, ISBN 91-972299-4-6.

[7] MRKVICA, I., KONDERLA, R., FAKTOR, M. (2012). Turning of Inconel 718 by Cemented Carbides. 6th International Con-gress of Precision Machining. In: Key Engineering Materials, vol. 496, pp. 138-147. ISSN $1013-$ 9826, ISBN 978-3-03785-297-2.

[8] MRKVICA, I., NESLUSAN, M., KONDERLA, R., JANOS, M. (2012). Cutting ceramic by turning of nickel alloy Inconel. In Manufacturing Technology. Vol. 12, No. 13, pp. 178-186. ISSN 1213-2489.

[9] PETRU, J., ZLAMAL, T., CEP, R., PAGAC, M., GREPL, M. (2013). Influence of Strengthening Effect on Machinability of the Welded Inconel 625 and of the Wrought Inconel 625. In IMETI 2013 Procedings of the 6th International Multi-Conference on Engineering and Technological Innovation, USA, Florida, Orlando, 9th - 12th July 2013. Orlando: International Institute of Informatics and Systematics, 1st edition + proceedings on CD, pp. $1-5$.

[10] STANCEKOVA, D., SEMCER, J., DERBAS, M., KURNAVA, T. (2013). Methods of measuring of residual stresses and evaluation of residual state of functional surfaces by x-ray diffractometric methods. In Manufacturing Technology. Vol. 4, pp. 547-552.ISSN 1213-2489.

[11] MICHALIK, P., ZAJAC, J., HATALA, M., MITAL, D., FECOVA, V. (2014). Monitoring surface roughness of thin-walled components from steel C45 machining down and up milling. In Measurement: Journal of the International Measurement Confederation, Vol. 58, pp. 416-428. ISSN 0263-2241.

[12] KRÓLCZYK, G., GAJEK, M., LEGUTKO, S. (2013. Effect of the cutting parameters impact onto tool life in duplex stainless steel turning process, Tehnički Vjesnik - Technical Gazette, 20, 4, pp. 587-592.

[13] KROLCZYK, G.M., NIESŁONY, P., LEGUTKO, S. (2015). Determination of tool life and research wear during duplex stainless steel turning, Archives of Civil and Mechanical Engineering, 15, 2, pp. 347 - 354.

[14] KRÓLCZYK, G., LEGUTKO, S., RAOS, P. (2013). Cutting wedge wear examination during turning of duplex stainless steel, Tehnički Vjesnik - Technical Gazette, 20, 3, pp. 413-418. 